\title{
Recalcitrant caustic burn wound and definitive treatment with medial plantar flap
}

\author{
Sinan Öksüz, M.D., Fikret Eren, M.D., Celalettin Sever, M.D., Hüseyin Karagöz, M.D., Ersin Ülkür, M.D.
}

Department of Plastic Reconstructive and Aesthetic Surgery, Burn Unit, GATA Haydarpasa Training Hospital, Istanbul

\begin{abstract}
Caustic chemicals cause destruction in tissues even long after the initial exposure. This study reported a case of recurrent graft lysis encountered throughout the treatment of a sodium hydroxide burn. A caustic burn on the ankle of a patient was reconstructed with split thickness skin grafts thrice in a period of four months. The burn site healed uneventfully after each skin grafting. However, weeks after each successful graft take, even though the patient did not experience any trauma at his operated ankle, an eczematous blistering at the skin graft site was observed. Thereafter, skin grafts almost totally sloughed over time even after each successful graft take. Six months after the initial burn and recurrent skin graft lysis, the defect site was reconstructed with medial plantar flap.At the postoperative ninth month follow-up, there was no sign of the blistering or skin loss at the burn area after definitive flap surgery. Recurrent graft lysis, in a few weeks after total skin graft take is an unusual complication for most of the burn cases. Caustic burns may have a deceptively superficial appearance concealing the chemical reactions that further damage the tissue. Therefore, early surgical interventions such as deep debridement and graft surgery should be kept in mind as primary treatment options.
\end{abstract}

Keywords: Caustic burn; chemical burn; definitive flap surgery; recurrent skin graft lysis.

\section{INTRODUCTION}

Chemical skin injuries are not common among burn patients. Alcali constitutes more than half of the chemical burn causes. [1,2] Sodium hydroxide is a widely used strong base chemical, also known as caustic soda or lye. Sodium hydroxide, as a thick liquid gel, dissolves grease, oils, fats and protein deposits in domestic use. Dissolution of pure sodium hydroxide in water ends up with a highly exothermic reaction. ${ }^{[3,4]}$ Unlike thermal injuries, caustic chemicals cause destruction in the tissue even long after the initial exposure. ${ }^{[5]}$ Sodium hydroxide burn is still an ongoing, underestimated and rarely reported problem for domestic environments.

This study reported a case of recurrent graft lysis encountered throughout the treatment of a sodium hydroxide burn along with the definitive treatment with medial plantar flap.

Address for correspondence: Sinan Öksüz, M.D.
GATA Haydarpaşa Eğitim Hastanesi, Plastik, Rekonstrüktif ve Estetik
Cerrahi Servisi ve Yanık Ünitesi, Istanbul Turkey
$\begin{array}{ll}\text { Tel: +90 216-444 I8 } 98 & \text { E-mail: sinanoksuz@gmail.com } \\ \text { Qucik Response Code } & \text { Ulus Travma Acil Cerrahi Derg } \\ & 2015 ; 21(5): 402-404 \\ \end{array}$
$\begin{array}{ll}\text { doi: } 10.5505 / t \text { tes.20I5.49386 } \\ \end{array}$

\section{CASE REPORT}

A 21 -year-old male spilled liquid caustic soda on his wet fabric clothing while cleaning an industrial dishwasher. A second degree caustic burn was determined on his left ankle five hours after the injury. The patient was treated with chlorhexidine impregnated gauze for ten hours before admission to our burn unit (Fig. Ia). Thereafter, the burn was treated with daily copious irrigation and dressings for seven days. Excision and autologous split thickness skin grafting was applied at postoperative tenth day. The burn site and the graft donor site healed uneventfully after skin grafting (Fig. Ib). Three weeks after the operation, the patient suffered from eczematous blistering at the skin graft site. The patient did not experience any mechanical trauma at his operated ankle before this blistering. However, spontaneous blistering and ulceration at the grafted burn site became prominent in a few days. One month after successful grafting and seven days after the first blister formation, the skin graft was almost totally sloughed (Fig. Ic). The patient was again treated with daily dressings for one week and operated afterwards for the second time. Remnants of skin graft at the caustic burn site, dermis and subdermal tissue under the graft were excised. The resulting skin defect was once again reconstructed with split thickness skin graft. There was a complete successful graft take during the second postoperative two weeks follow up period. Nevertheless, at the second postoperative third week, an exudative and eczematous skin reaction was observed over the skin 

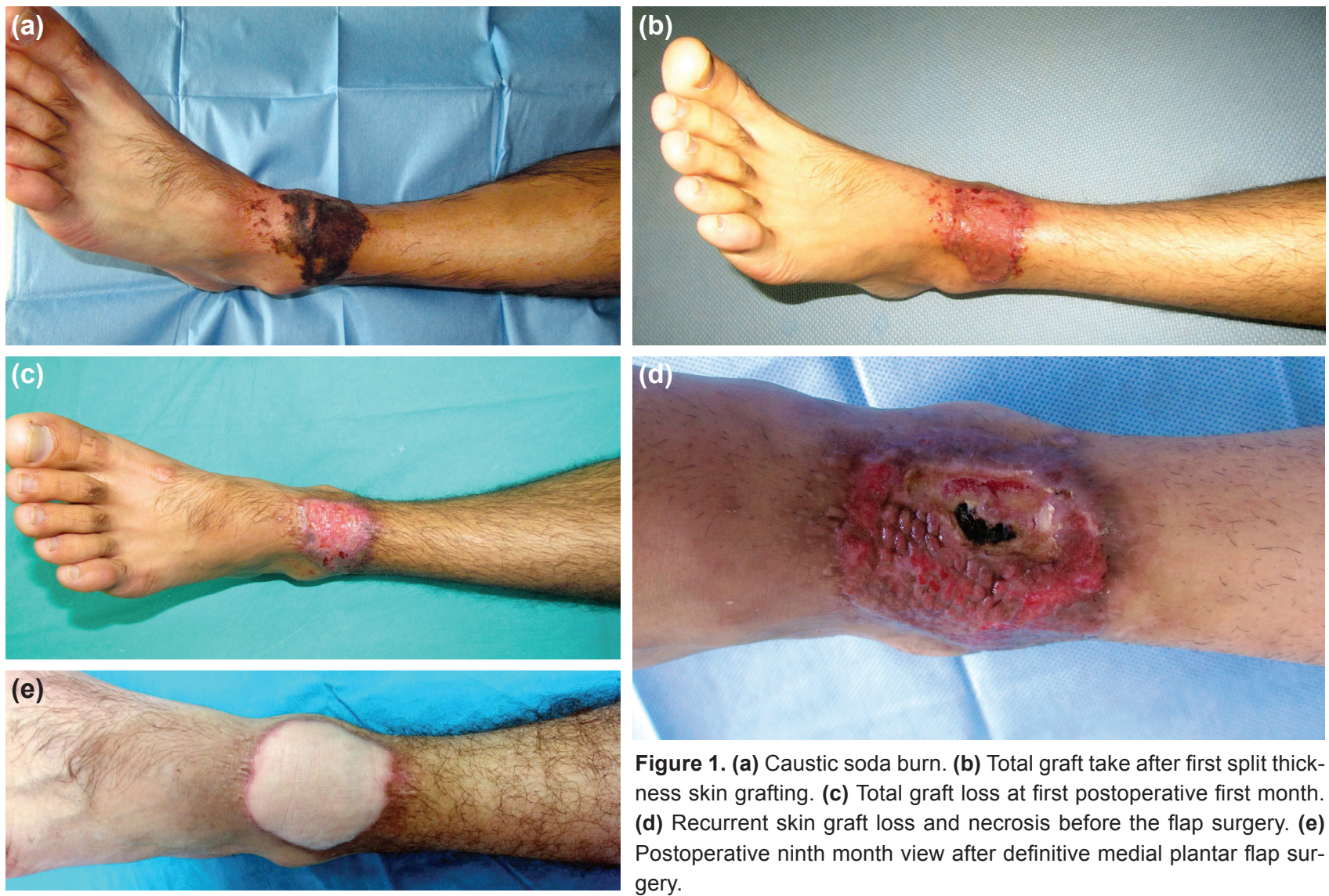

Figure 1. (a) Caustic soda burn. (b) Total graft take after first split thickness skin grafting. (c) Total graft loss at first postoperative first month. (d) Recurrent skin graft loss and necrosis before the flap surgery. (e) Postoperative ninth month view after definitive medial plantar flap surgery.

graft. Thereafter, eczematous lesion at the ankle skin graft site proceeded to a partial open wound one month after the second operation. After all, by the post-burn second month, the patient was operated twice due to the recurrent skin graft lysis and was still suffering from a partial open wound. Thereupon, the latest skin graft lysis site was decided to be managed with dressings due to limited skin loss and seemingly well vascular supply of the wound. However, at the post-burn third month, the graft was totally lost. A third skin grafting was performed and a successful take was observed for only four weeks. Afterwards, recurrence of the blistering, skin loss and necrosis was once again determined at the trauma zone (Fig. Id). Finally, total full thickness excision of the burn area to the paratenon was executed, and the defect site was reconstructed with the completely healthy skin paddle of the medial plantar flap. Finally, the burn site healed uneventfully.

The caustic burn was reconstructed with split thickness skin grafts thrice in a period of four months. The burn site healed uneventfully after each skin grafting. Nevertheless, the remission of the lesion lasted for only one month utmost. Even though the patient did not experience any trauma at his operated ankle, an eczematous blistering at the skin graft site was observed. Thereafter, skin grafts almost totally sloughed over time after each successful graft take. Six months after the initial burn and recurrent skin graft lysis, the defect site was reconstructed with medial plantar flap. At the postop- erative ninth month follow-up, there was no sign of blistering or skin loss at the burn area after the final definitive flap surgery (Fig. Ie).

\section{DISCUSSION}

Dilution or neutralization of the chemical agents with copious water or saline irrigation reduces concentration of the chemicals and duration of exposure time. Tissue injury proceeds if the toxic effects of the chemicals are not neutralized properly by irrigation. Caustic soda exposes the tissue to a high concentration of hydroxide ions $\left(\mathrm{OH}^{-}\right)$, which results in saponification of fat and formation of soluble alcaline proteinates. Such reactions triggered by caustic agents also have an exothermic nature that causes further tissue damage. ${ }^{[6]}$ Emergency treatment of caustic contact is similar to most chemical injuries. Removal of the involved clothing and immediate copious water irrigation, sometimes even up to 12 hours, are essential. Prompt and long lasting skin irrigation to neutralize the caustic effect is crucial in reducing the depth of the injury. ${ }^{[1,6]}$ In this case, there was a failure in immediate copious irrigation.

Delayed post-burn blistering is a casual phenomenon that occurs after healing of second degree burns or donor sites of split thickness skin grafts. Discontinuity of the basement membrane is assumed as the main anomaly due to the dis- 
turbance in the reassembly or local breakdown of the basement membrane components in delayed post-burn blistering. [7] Minor traumas such as rubbing or friction is also some other etiologic factors for blistering. ${ }^{[8]}$ In either etiology, graft lysis due to delayed blistering is rarely reported at the transplantation sites of autologous split thickness skin grafts after full take. ${ }^{[7]}$ Likewise, blistering of the skin graft after caustic burn is also rare. ${ }^{[5,9]}$ To the best of our knowledge, repeated episodes of blistering and necrosis following alcali burn is reported only for one case in a long term follow-up period. Besides, recurrent graft lysis in a few weeks after total skin graft take without any trauma is an unusual complication for most of the burn cases. Proper emergency treatment, early excision of the caustic burn site and reconstruction with skin graft are considered to be a preventive measure for delayed blistering. If early excision and skin grafting operation chances are missed, delayed surgical treatment may necessitate deeper excision and flap surgery. ${ }^{[5]}$

Nevertheless, in this reported case, even though an early excision and skin grafting was performed ten days after the burn, the patient still encountered a total graft lysis due to delayed blisters three weeks after the initial operation. Recurrent graft loss even after the third operation, in this case, necessitated a definitive treatment with medial plantar flap.

After caustic burns, initial treatment should focus on preventing the latent extension of necrosis to the deep dermal tissues. ${ }^{[9]}$ The caustic burn may have a deceptively superficial appearance concealing the chemical reactions that further damage the tissue. ${ }^{[5]}$ Therefore, early surgical interventions with flap options should be kept in mind as the primary treatment option for an alcali burn, instead of applying dressings for the long term. During initial surgery, excision depth of the affected site should be determined by considering the recur- rent blistering nature of the skin graft after caustic burn. The deeper layers of the dermis should better be excised even at an early surgical intervention to prevent the future graft lysis risk.

In order to abstain from long lasting, time consuming treatments and potential failure of the autologous skin grafts, the consumers also should be aware of caustic soda burn and wear water proof clothing when using and handling caustic soda. Manuals and the package tags should contain clear instructions and visible warnings about health hazards concerning chemical burns.

Conflict of interest: None declared.

\section{REFERENCES}

1. Mozingo DW, Smith AA, McManus WF, Pruitt BA Jr, Mason AD Jr. Chemical burns. J Trauma 1988;28:642-7. CrossRef

2. Hardwicke J, Hunter T, Staruch R, Moiemen N. Chemical burns-an historical comparison and review of the literature. Burns 2012;38:383-7.

3. Bromberg Be, Song Ic, Walden Rh. Hydrotherapy Of Chemical Burns. Plast Reconstr Surg 1965;35:85-95. CrossRef

4. Steinberg Uw, Walden Rh, Bromberg Be, Rubin Lr, Hermann Wf. Hydrotherapy of lye burns. Plast Reconstr Surg 1963;31:481-4. CrossRef

5. Maguina P, Busse B. Local tissue flaps: definitive treatment for chronic blisters after chemical burns. J Burn Care Res 2011;32:e140-2. CrossRef

6. Sykes RA, Mani MM, Hiebert JM. Chemical burns: retrospective review. J Burn Care Rehabil 1986;7:343-7. CrossRef

7. Bergman R, David R, Ramon Y, Ramon M, Kerner H, Kilim S, et al. Delayed postburn blisters: an immunohistochemical and ultrastructural study. J Cutan Pathol 1997;24:429-33. CrossRef

8. Pedragosa R, Serrano S, Carol-Murillo J, Hernandez JV, Vidal J. Blisters over burn scars in a child. Br J Dermatol 1986;115:501-6. CrossRef

9. O'Donoghue JM, Al-Ghazal SK, McCann JJ. Caustic soda burns to the extremities: difficulties in management. Br J Clin Pract 1996;50:10810 .

\section{OLGU SUNUMU - ÖZET}

\section{Tedaviye dirençli kostik yanık yarası ve medial plantar flep ile yapılan kesin tedavisi Dr. Sinan Öksüz, Dr. Fikret Eren, Dr. Celalettin Sever, Dr. Hüseyin Karagöz, Dr. Ersin Ülkür

\author{
Gülhane Askeri Tıp Akademisi Haydarpaşa Eğitim Hastanesi, Plastik, Rekonstrüktif ve Estetik Cerrahi Servisi ve Yanık Ünitesi, İstanbul
}

Kostik kimyasallar ilk temastan çok uzun süre sonra bile dokuda hasara neden olurlar. Bu yazıda, sodyum hidroksit yanık olgusunda tedavisi sırasında gözlenen tekrar eden greft kaybı sunuldu. Hastanın ayak bileğindeki kostik yanık dört aylık dönem içinde üç kere kısmi kalınlıkta deri grefti ile onarıldı. Her greftlemeden sonra yanık bölgesi sorunsuz olarak iyileşti. Ancak başarılı olan her bir greftlemeden haftalar sonra, hastanın ameliyat edilen ayak bileği travmaya maruz kalmamasına rağmen, deri grefti uygulanan bölgede ekzematöz blister oluşumu gözlendi. Bunun ardından başarılı greftleme ve iyileşmeye rağmen deri greftleri tamama yakın oranda soyuldu. İlk yanıktan ve tekrar eden deri grefti kayıplarından altı ay sonra defekt alanı medial plantar flep ile onarıldı. Flep ameliyatı ardından dokuzuncu ay takibinde yanık alanında herhangi bir blister oluşumu bulgusu veya deri kaybı gözlenmedi. Tamamen başarılı olmuş deri grefti uygulaması ardından birkaç hafta içinde tekrar eden greft kayıpları gözlenmesi pek çok yanık olgusu için sıradışı bir komplikasyondur. Kostik yanıklar dokuya zarar vermeye devam eden kimyasal reaksiyonları gizleyen aldatıcı bir yüzeysel görünüme sahip olabilir. Bu nedenle ilk tedavi seçeneği olarak derin debridman ve greft cerrahisi gibi erken cerrahi müdahaleler akılda bulundurulmalıdır. Anahtar sözcükler: Kesin flep cerrahisi; kimyasal yanık, kostik yanık; tekrar eden deri grefti kaybı.

Ulus Travma Acil Cerrahi Derg 20I5;2I(5):402-404 doi: 10.5505/tjtes.20I5.49386 